\title{
Cascade radical cyclization of polyolefinic vinyl iodides: comparison between 5-exo and 6-endo cyclization of vinyl radicals
}

\author{
Soumen Maiti, Kiyosei Takasu, ${ }^{*}$ Akira Katsumata, \\ Jun-ichi Kuroyanagi, and Masataka Ihara* \\ Department of Organic Chemistry, Graduate School of Pharmaceutical Sciences, Tohoku \\ University, Aobayama, Sendai 980-8578, Japan \\ E-mail: mihara@mail.pharm.tohoku.ac.jp
}

Dedicated to Professor S. V. Kessar on the occasion of his $70^{\text {th }}$ birthday

(received 18 Jul 02; accepted 11 Sep 02; published on the web 19 Sep 02)

\begin{abstract}
We herein describe sequential radical cyclization of acyclic polyenes having a vinyliodide moiety that can act as both of a radical donor and an acceptor during the same reaction. The regioselectivity is extremely dependent on the substrate structure. Tricyclo[8.4.0.0 $\left.0^{2,7}\right]$ tetradecene and tricyclo[6.3.0.0 $\left.0^{2,6}\right]$ undecane were obtained by cascade radical cyclization from the welldesigned substrates, 1-iodo-1,5,9,14-tetraene and 1-iodo-1,5,10-triene, in a single operation.
\end{abstract}

Keywords: Cascade reaction, radical reaction, regioselectivity, vinyl radicals, polycyclic systems

\section{Introduction}

Radical reactions have become valuable tools for the construction of complex molecules and have solved various fundamental problems associated with ionic reactions. ${ }^{1}$ Out of various types of radical reaction, the cascade (tandem) reaction is one of the most powerful methods to construct a polycyclic ring system in one step from unsaturated acyclic precursors. ${ }^{2}$ It is well documented that 5-alkenyl radicals (alkyl radicals) predominantly undergo 5-exo cyclization to give 5-membered products over the 6-endo mode. ${ }^{3}$ The cascade 5-exo radical cyclization reactions based on the above feature have been developed to synthesize polycyclic 5-membered compounds. ${ }^{4}$ Although the examples were limited, cascade 6-endo radical cyclizations were investigated and utilized in the syntheses of steroidal skeletons. It was made clear that ketyl radicals are effective for consecutive 6-endo cyclization. ${ }^{5}$ On the other hand, in 1980s Beckwith and Stork have independently reported that the use of vinyl radicals for a ring closure has shown unique behavior indicating an equilibrium between 5-exo and 6-endo cyclizations. ${ }^{6,7}$ In this paper 
we try to focus on the cascade radical cyclization of vinyl radicals to assemble terpenoid frameworks from simple polyolefinic materials. ${ }^{8}$

\section{Results and Discussion}

As a preliminary experiment, we examined the intramolecular radical cyclization of a vinyl iodide with a trisubstituted olefin moiety. The iodo olefinic substrate $\mathbf{1}$ was readily prepared from 1-(tert-butyldimethylsiloxy)pentanal (2) ${ }^{9}$ in four steps (Scheme 1). Allylic alcohol 3 was prepared by Barbier reaction of 2 in $89 \%$ yield under the ultrasonic circumstance. After $O$ vinylation of $\mathbf{3}$, the corresponding ether $\mathbf{4}$ was transformed into vinyl iodide $\mathbf{1}$ by Claisen rearrangement, followed by $Z$-selective Wittig olefination. ${ }^{10}$

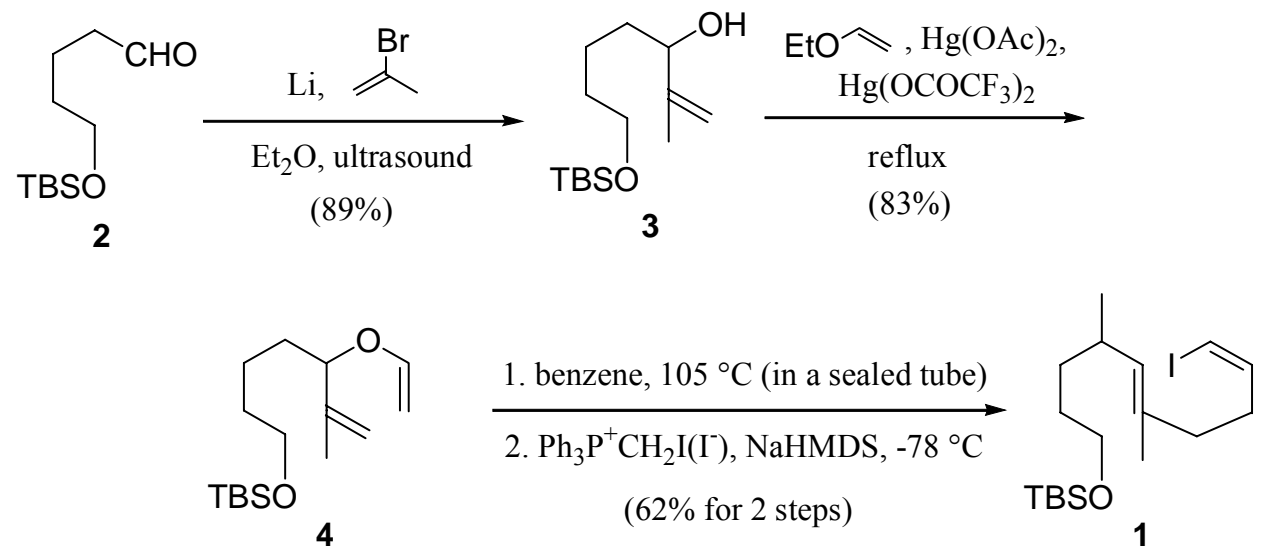

Scheme 1. Preparation of 1-iodo-1,5-diene 1.

The radical reactions were performed by using $\mathrm{Bu}_{3} \mathrm{SnH}$ (TBTH) in the presence of a catalytic amount of AIBN or $\mathrm{Et}_{3} \mathrm{~B}-\mathrm{O}_{2}$ as a radical initiator (Table 1). Under refluxing conditions in benzene at $80{ }^{\circ} \mathrm{C}, \mathbf{1}$ was transformed into the cyclohexene $\mathbf{6 a}$, which was isolated as $\mathbf{6 b}$, after deprotection of the silyl group, as a diastereomeric mixture in the ratio of $1: 3.5$ (entry 1 ). On the other hand, the treatment of 1 at low temperature $\left(-40^{\circ} \mathrm{C}\right)$, followed by desilylation, provided the cyclopentene $\mathbf{5 b}$ as a major product along with $\mathbf{6 b}$ (entry 2). The formation of the 6-endo adduct under thermodynamic conditions can be explained as follows based on homoallyl-homoallyl radical rearrangement. ${ }^{11}$ The radical reaction initially proceeds through 5-exo cyclization in accordance with Baldwin's rule ${ }^{12}$ to give the secondary radical species 7 . At higher temperature the 5-exo adduct 7 further cyclizes by 3-exo manner to give the unstable intermediate 8 . Cyclopropylcarbinyl radical $\mathbf{8}$ is rapidly transformed by $\beta$-scission into the thermodynamically stable tertiary radical $\mathbf{9}$, which was consequently transformed into the 6-endo product $\mathbf{6 a}$. Thus, 5-exo or 6-endo adducts could be synthesized from the vinyl radical precursor by changing the reaction temperature. 
Table 1. Radical cyclization of 1-iodo-1,5-diene 1

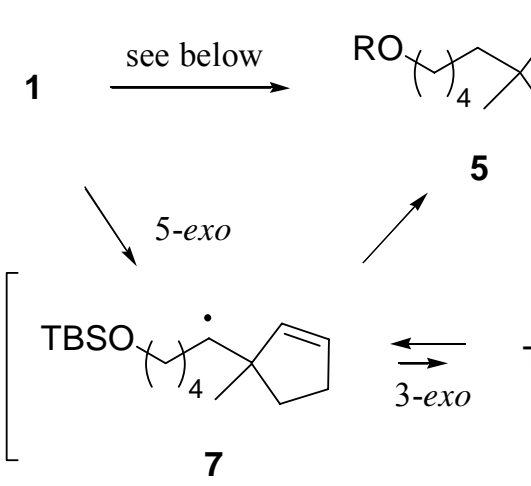

7

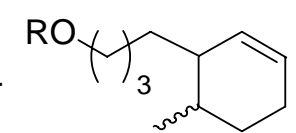

6 $\left.\begin{array}{l}\mathbf{a}: \mathrm{R}=\mathrm{TBS} \\ \mathbf{b}: \mathrm{R}=\mathrm{H}\end{array}\right] \mathrm{AcOH}, \mathrm{H}_{2} \mathrm{O}$

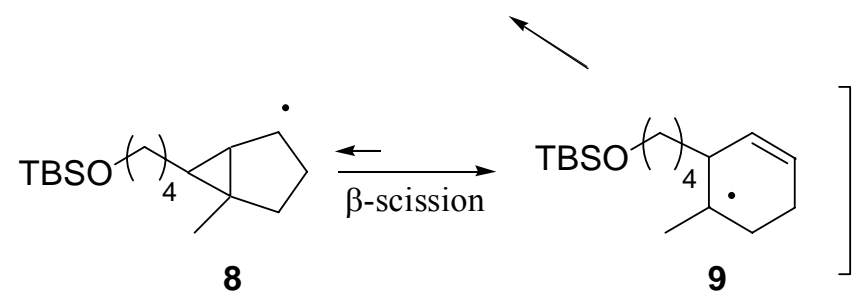

9

\begin{tabular}{clcc}
\hline entry & \multicolumn{1}{c}{ conditions } & $\begin{array}{c}\text { cyclized yield } \\
(\%)^{a}\end{array}$ & $\begin{array}{c}\text { ratio }^{b} \\
\left(\mathbf{5 b}: \mathbf{6} \mathbf{b}^{c}\right)\end{array}$ \\
\hline 1 & $\mathrm{Bu}_{3} \mathrm{SnH}, \mathrm{AIBN}$, benzene $(1 \mathrm{mM})$, reflux & 70 & $0: 1$ \\
2 & $\mathrm{Bu}_{3} \mathrm{SnH}, \mathrm{Et}_{3} \mathrm{~B}, \mathrm{O}_{2}$, toluene $(1 \mathrm{mM}),-40^{\circ} \mathrm{C}$ & 85 & $2: 1$ \\
\hline
\end{tabular}

${ }^{a}$ Overall yield in 2 steps. ${ }^{b}$ The ratio was determined by ${ }^{1} \mathrm{H}-\mathrm{NMR}$.

${ }^{c}$ 6b was obtained as a 3.5:1 diastereomeric mixture.

Next, we planned the sequential radical cyclization of suitably functionalized acyclic substrates to construct polycyclic skeletons. We rationally designed vinyl iodides $\mathbf{1 0}$ and $\mathbf{1 1}$ as geranylgeranyl and farnesyl motifs, respectively. The terminal unsaturated ester moiety was anticipated to act as a good acceptor to accelerate the radical addition. ${ }^{13}$ 1-Iodo-1,5,9,14tetraenoate 10 was prepared from 4 in 8 steps (Scheme 2). Allyl alcohol 12 was prepared by Claisen rearrangement of 4 , followed by Barbier reaction with 2-bromopropene. $O$-Vinylation of 12 provided vinyl ether 13 in 98\% yield. Vinyl iodide 14 was prepared by Claisen rearrangement of 13, followed by Wittig olefination and desilylation. 14 was obtained as a single isomer having $Z$ configuration with respect to the iodo olefine double bond. Oxidation of hydroxyl group of 14 with Dess-Martin periodinane, ${ }^{14}$ followed by HWE reaction, afforded the key substrate $\mathbf{1 0}$.

1-Iodo-1,5,10-trienoate $\mathbf{1 1}$ was prepared by a short sequence of reactions as shown in Scheme 3. Dimethyl malonate was mono-alkylated with geranyl bromide to afford diene 15 in $71 \%$ yield, and further alkylation of 15 with methyl 4-bromocrotonate gave trienoate $\mathbf{1 6}$ in $92 \%$ yield. The treatment of $\mathbf{1 6}$ with a catalytic amount of osmium tetroxide in the presence of $\mathrm{N}$ methylmorpholine oxide (NMO), followed by oxidative cleavage of the corresponding diol by sodium periodate, provided the desired aldehyde 17 (83\% overall yield in two step). (Z)-Vinyl iodide 11 was prepared by Wittig reaction of $\mathbf{1 7}$ in 57\% yield as a single isomer. 

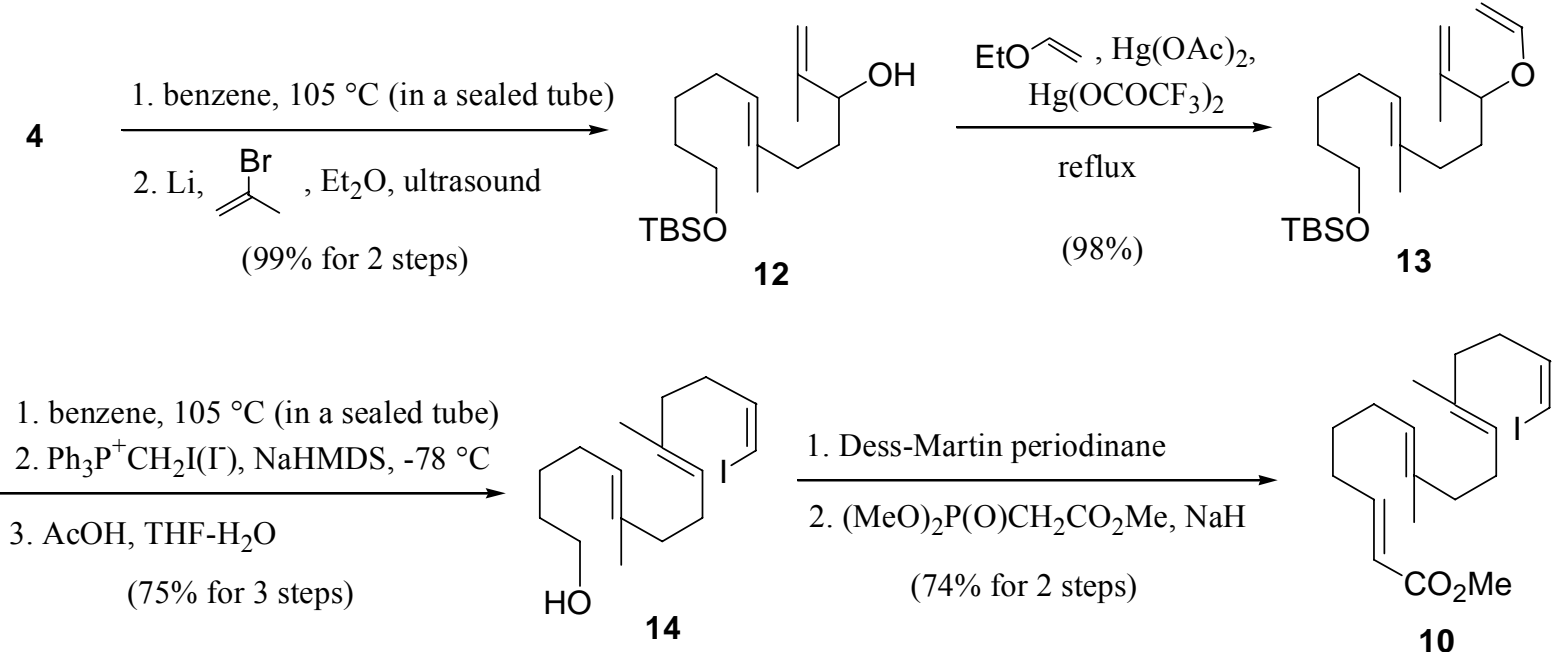

Scheme 2. Preparation of 1-iodo-1,5,9,14-tetraene 10.
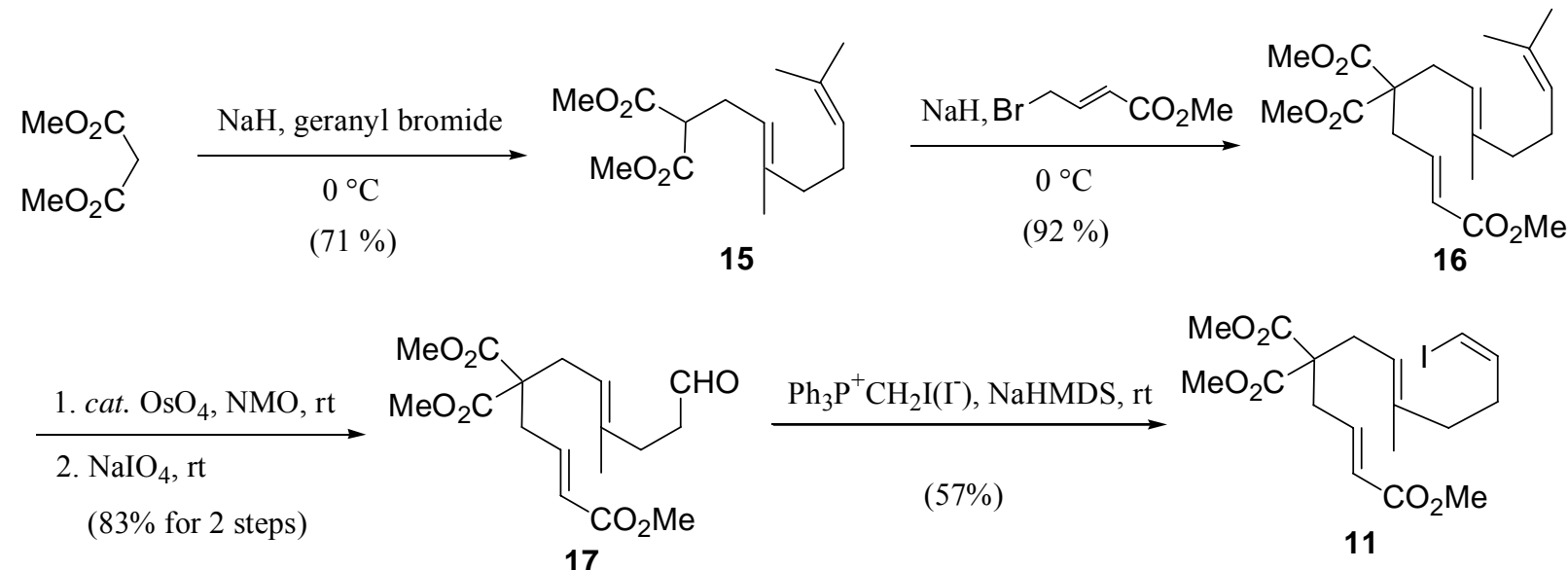

Scheme 3. Preparation of 1-iodo-1,5,10-triene 11.

The radical reaction of tetraene $\mathbf{1 0}$ was examined under various conditions; reductive electrolysis, ${ }^{15}$ TBTH method, and tris(trimethylsilyl)silane (TTMSH) method (Table 2). The electrolysis, mediated by $\mathrm{Ni}(\text { cyclam })^{2+}$ of $\mathbf{1 0}$ at room temperature, yielded the dodecahydrophenanthrene derivative 18, the cyclopentene derivative 19, and other cyclized products with a $5: 2: 3$ ratio in low yield (entry 1). The formation of 18 results from the 6-endo, 6-endo, 6-exo cascade cyclization. When the reaction was performed at $100{ }^{\circ} \mathrm{C}$, the ratio of 18 increased considerably but the yield was still low (entry 2). On the other hand, when 10 was exposed to thermal conditions by using TBTH or TTMSH, the desired cascade cyclization proceeded in high yield to give $\mathbf{1 8}$ as a major product (entries 3 and 4). Especially, the treatment with TTMSH-AIBN at $80{ }^{\circ} \mathrm{C}$ exclusively afforded 18 in $77 \%$ yield. The structure of 18 was 
established by the spectral analysis after conversion of the olefin moiety into the carbonyl function, ${ }^{16}$ although the stereochemistry was not determined owing to difficulty of separation of each diastereomer. The free radical reaction at $-40{ }^{\circ} \mathrm{C}$ using $\mathrm{TBTH}-\mathrm{Et}_{3} \mathrm{~B}$ in the presence of $\mathrm{O}_{2}$ gas gave only 19 in very high yield (entry 5).

Table 2. Radical cyclization of 1-iodo-1,5,9,14-tetraene 10

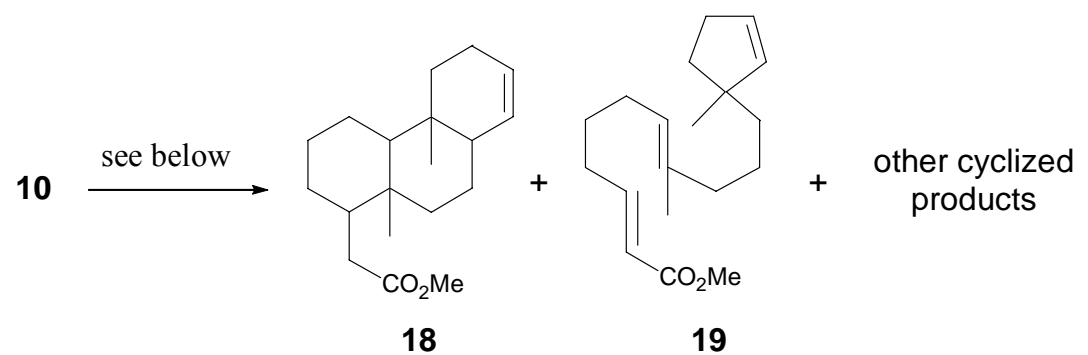

\begin{tabular}{|c|c|c|c|}
\hline Entry & Conditions & $\%$ Yield & $\begin{array}{c}\text { Ratio }^{a} \\
\left(\mathbf{1 8}^{b}: \mathbf{1 9} \text { : } \text { others }^{c}\right)\end{array}$ \\
\hline 1 & $\mathrm{Ni}($ cyclam $)\left(\mathrm{ClO}_{4}\right)_{2}, \mathrm{NH}_{4} \mathrm{ClO}_{4}, \mathrm{DMF},-1.5 \mathrm{~V}, \mathrm{rt}$ & 22 & $5: 2: 3$ \\
\hline 2 & $\mathrm{Ni}($ cyclam $)\left(\mathrm{ClO}_{4}\right)_{2}, \mathrm{NH}_{4} \mathrm{ClO}_{4}, \mathrm{DMF},-1.5 \mathrm{~V}, 100^{\circ} \mathrm{C}$ & 39 & $8: 0: 2$ \\
\hline 3 & $\mathrm{Bu}_{3} \mathrm{SnH}, \mathrm{AIBN}$, benzene $(1 \mathrm{mM})$, reflux & 76 & $8.5: 0: 1.5$ \\
\hline 4 & $(\mathrm{TMS})_{3} \mathrm{SiH}, \mathrm{AIBN}$, benzene $(1 \mathrm{mM})$, reflux & 77 & $10: 0: 0$ \\
\hline 5 & $\mathrm{Bu}_{3} \mathrm{SnH}, \mathrm{Et}_{3} \mathrm{~B}, \mathrm{O}_{2}$, toluene $(1 \mathrm{mM}),-40^{\circ} \mathrm{C}$ & 94 & $0: 10: 0$ \\
\hline
\end{tabular}

${ }^{a}$ Ratio was determined by ${ }^{1} \mathrm{H}-\mathrm{NMR} .{ }^{b} \mathbf{1 8}$ was obtained as a 4:4:1:1 diastereomeric mixture.

${ }^{c}$ The structures were not determined.

In contrast, the radical reaction of 1-iodo-1,5,10-trienoate 11, which lacks one isoprene unit compared with 10, gives quite different results. ${ }^{17}$ The radical cyclization reaction of 11 was conducted under similar conditions as above (Table 3). The reaction with TBTH-AIBN under refluxing conditions afforded tricyclo[6.3.0.0 $\left.0^{2,6}\right]$ undecanes 20 in $80 \%$ yield as a mixture of more than four isomers (entry 1). The cascade reaction proceeded to give a linear-triquinane framework, but unselective formation of several diastereomers was observed. At room temperature the number of stereoisomers was reduced; treatment with $\mathrm{TBTH}_{-} \mathrm{Et}_{3} \mathrm{~B}$ at room temperature afforded only two isomers, 20a and 20b, in $83 \%$ yield with a ratio of $4: 3$ (entry 2). However, when the temperature was further lowered $\left(-40^{\circ} \mathrm{C}\right)$, the yields of mono and doublecyclized products were increased (entry 3). The TTMSH method gave almost similar results to the TBTH method (entries 4 and 5). On the contrary, the cathodic electrolysis, mediated by $\mathrm{Ni}(\text { cyclam })^{2+}$, afforded poor production of $\mathbf{2 0}$ (entries 6 and 7). 
Table 3. Radical cyclization of 1-iodo-1,5,10-triene $\mathbf{1 1}$

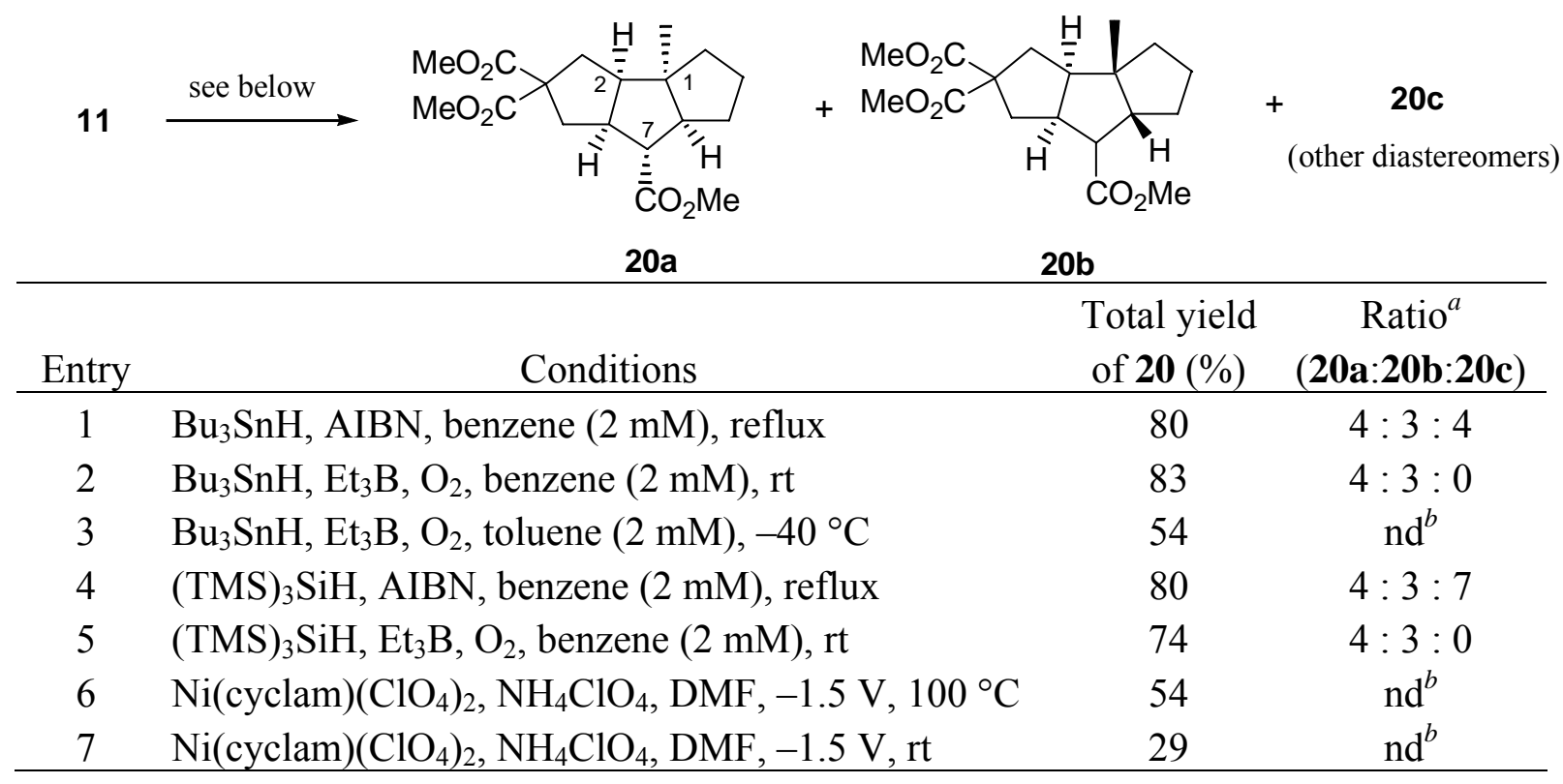

${ }^{a}$ Ratio of 20a, 20b and 20c was determined by ${ }^{1} \mathrm{H}-\mathrm{NMR} .{ }^{b}$ "nd" means "not determined".

After a careful purification by column chromatography on silica gel, only 20a was separated from the mixture of 20a and 20b (from entry 2 in Table 3). The structural assignment of 20a was achieved on the basis of detailed 2D NMR experiments (NOE correlation was shown in Figure 1). Its framework was determined as a cis-syn-cis linear-triquinane and the methoxycarbonyl group at $\mathrm{C}$ (7) was located on the convex side of the skeleton. On the contrary, isolation of 20b could not be achieved by any efforts. No epimerization of 20a occurred by treatment with DBU under thermodynamic conditions or by LDA under kinetic conditions. It indicates that the acidic proton at $\mathrm{C}$ (7) of 20a stands on the sterically hindered position. When a mixture of 20a and 20b was subjected to kinetic deprotonation conditions (LDA, then aqueous work up), a new epimer was obtained along with 20a and 20b. This suggests that the new epimer is the diastereomer of 20b and, moreover, 20b has a different stereochemistry of a linear-triquinane skeleton from 20a. Based on the mechanistic aspect and Curran's previous results, ${ }^{17}$ the framework of $20 \mathbf{b}$ might be cis-anti-cis configuration.

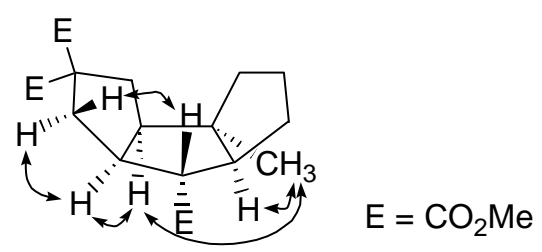

Figure 1. Characteristic NOEs for 20a. 
It is interesting to observe that the radical reactions of acyclic isoprenoid analogs $\mathbf{1 0}$ and $\mathbf{1 1}$ proceed in different cyclization manners. The reaction of geranylgeranyl analog $\mathbf{1 0}$ produces tricyclo[8.4.0.0 $\left.0^{2,7}\right]$ tetradecene 18, which is a linear fused six-membered ring carbocycle, through a sequential 6-endo, 6-endo, 6-exo cyclization. Whereas a 5-exo, 5-exo, 5-exo cyclization proceeds in the case of farnesyl analog 11 to give tricylo[6.3.0.0 $\left.0^{2,6}\right]$ undacane 20, which is a linear fused five-membered ring carbocycle. The reaction pathways of tetraene $\mathbf{1 0}$ and triene $\mathbf{1 1}$ can be rationally explained as shown in Scheme 4. In both case, the first radical cyclizations of corresponding 21 and $\mathbf{2 6}$ proceed through the kinetically favored 5-exo cyclization to form cyclopentenyl intermediates 22 and 27, respectively. But the cascade sequences may be firmly dependent on the regioselectivity at the second stage of the radical addition. In the former case, 3-exo-trig cyclization undergoes to give intermediate 23 under the thermodynamic conditions, whereas 5-endo-trig cyclization with another olefin moiety can be ruled out by Baldwin's rule. Unstable intermediate $\mathbf{2 3}$ is rearranged into thermodynamically stable tertiary alkyl radical $\mathbf{2 4}$, which is consistent with the formal 6-endo-trig cyclized intermediate from vinyl radical 21. In the third radical cyclization stage, due to the steric effect, the 6-endo cyclization may be predominant over 5-exo to afford bicyclic radical 25. ${ }^{18}$ Finally, the radical reaction completes by the sequential 6-exo-trig cyclization to give the decahydrophenanthrene adduct $\mathbf{1 8}$. On the contrary, in the reaction of $\mathbf{1 1}$, cyclized radical intermediate $\mathbf{2 7}$ will be converted into $\mathbf{2 8}$ by means of the 5-exo-trig cyclization. 5-Exo cyclization should be much preferred to 3-exo-trig one owing to the stereoelectronic effect. ${ }^{19}$ Final 5-exo-trig radical cyclization of 28, followed by hydride abstraction, furnishes the linear-triquinane adduct 20. The complementary results of radical reactions of $\mathbf{1 0}$ and $\mathbf{1 1}$ will be attributed to the characteristic features of radical cascades.

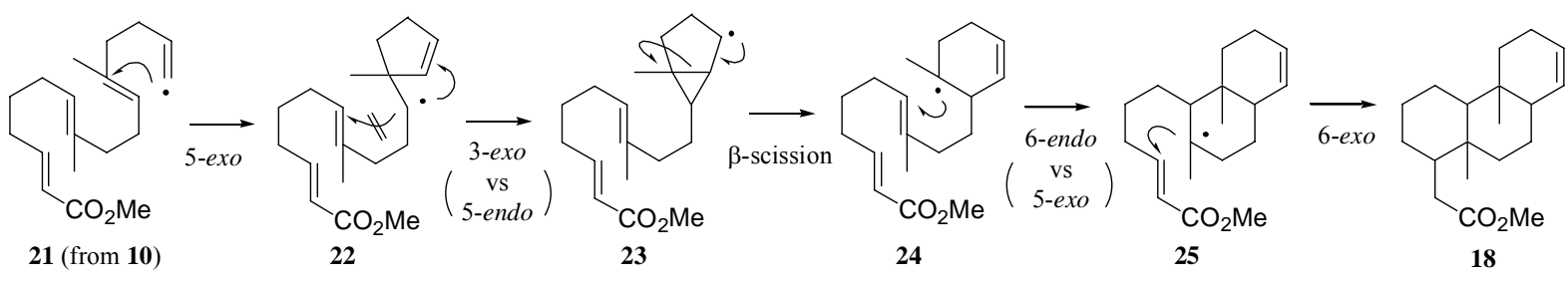

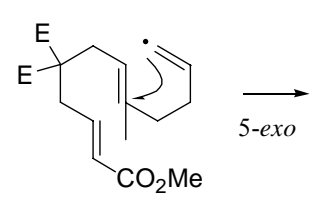

26 (from 11)

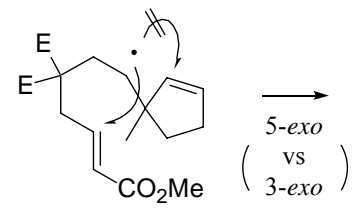

27

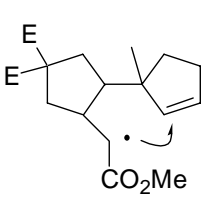

28
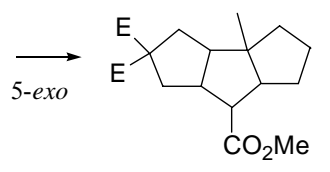

20

Scheme 4. Proposal mechanisms of cascade radical reaction of tetraene $\mathbf{1 0}$ and triene $\mathbf{1 1 .}$

In summary, tricyclo[8.4.0.0 $\left.0^{2,7}\right]$ tetradecene $\mathbf{1 8}$ and tricyclo[6.3.0.0 $\left.0^{2,6}\right]$ undecane 20 were obtained by cascade radical cyclization from 1-iodo-1,5,9,14-tetraene $\mathbf{1 0}$ and 1-iodo-1,5,10triene 11, respectively, in a single operation. The reactivity and selectivity of the cascade reaction can be controlled by the rational design of the substrate, such as incorporation of an 
isoprene unit or the introduction of terminal ester function. Further studies will pave way for the facile total syntheses of various natural products.

\section{Experimental Section}

General. Procedures. All reactions were carried out under an inert atmosphere. Anhydrous $\mathrm{THF}, \mathrm{Et}_{2} \mathrm{O}, \mathrm{MeCN}$, and $\mathrm{CH}_{2} \mathrm{Cl}_{2}$ were purchased from the Kanto Chemical Co., Inc. Toluene, DME and benzene were distilled from $\mathrm{CaH}_{2}$ under atmospheric. Unless otherwise described, the materials were obtained from commercial suppliers and used without further purification. Organic extracts were dried over $\mathrm{MgSO}_{4}$, filtered and concentrated under reduced pressure using an evaporator. Unless otherwise described, the ${ }^{1} \mathrm{H}$ and ${ }^{13} \mathrm{C}$ NMR spectra were recorded at 300 and $75 \mathrm{MHz}$, respectively, and were reported in ppm downfield from TMS $(\delta=0)$ for the ${ }^{1} \mathrm{H}$ NMR and relative to the central $\mathrm{CDCl}_{3}$ resonance $(\delta=77.00)$ for the ${ }^{13} \mathrm{C}$ NMR.

7-tert-Butyldimethylsiloxy-2-methyl-1-hepten-3-ol (3). To a suspension of Li (321 mg, $46.3 \mathrm{mmol})$ in $\mathrm{Et}_{2} \mathrm{O}(50 \mathrm{~mL})$ was added a solution of 2-bromopropene $(1.23 \mathrm{~mL}, 13.9 \mathrm{mmol})$ in $\mathrm{Et}_{2} \mathrm{O}(3 \mathrm{~mL})$ at $0{ }^{\circ} \mathrm{C}$, and then the mixture was irradiated of an ultrasonic cleaner $(30 \mathrm{~W})$ at $0{ }^{\circ} \mathrm{C}$ for $2 \mathrm{~h}$. After the slow addition of a solution of the aldehyde $2(2.00 \mathrm{~g}, 9.25 \mathrm{mmol})$ in $\mathrm{Et}_{2} \mathrm{O}$ $(10 \mathrm{~mL})$ at $0{ }^{\circ} \mathrm{C}$, the resulting mixture was continued to be irradiated at the same temperature for $10 \mathrm{~min}$. The mixture was quenched with sat. $\mathrm{NH}_{4} \mathrm{Cl}$ at $0{ }^{\circ} \mathrm{C}$, and then the resulting mixture was extracted with $\mathrm{Et}_{2} \mathrm{O}$. The organic extracts were washed with brine, dried, filtered, and evaporated to give a crude product. Chromatography of the residue on silica gel (19: 1 hexane/EtOAc) furnished $3(2.13 \mathrm{~g}, 89 \%)$ as colorless oil. IR (neat) v 3670-3100, 2950, 2860, 1470, 1460, 1260, 1100, 840, $780 \mathrm{~cm}^{-1} ;{ }^{1} \mathrm{H}$ NMR $\left(\mathrm{CDCl}_{3}\right) \delta 4.89(\mathrm{~s}, 1 \mathrm{H}), 4.79(\mathrm{~s}, 1 \mathrm{H}), 4.05-3.99(\mathrm{~m}, 1 \mathrm{H}), 3.57(\mathrm{t}, J$ $=6.6 \mathrm{~Hz}, 2 \mathrm{H}), 1.68(\mathrm{~s}, 3 \mathrm{H}), 1.65-1.42(\mathrm{~m}, 5 \mathrm{H}), 1.41-1.23(\mathrm{~m}, 2 \mathrm{H}), 0.85(\mathrm{~s}, 9 \mathrm{H}), 0.00(\mathrm{~s}, 6 \mathrm{H})$; ${ }^{13} \mathrm{C} \mathrm{NMR}\left(\mathrm{CDCl}_{3}\right) \delta 147.8,111.1,76.0,63.2,34.6,32.6,25.9,21.9,18.3,17.4,-5.4 ; \mathrm{LRMS} \mathrm{m} / \mathrm{z}$ (rel intensity) $201\left(1, \mathrm{M}^{+}-\mathrm{B} \mathrm{Bu}\right), 109$ (100). Anal. Calcd for $\mathrm{C}_{14} \mathrm{H}_{30} \mathrm{O}_{2} \mathrm{Si}: \mathrm{C}, 65.06 ; \mathrm{H}, 11.70$. Found: C, 65.04; H, 11.40.

7-tert-Butyldimethylsiloxy-2-methyl-3-vinyloxy-1-heptene (4). To a stirred solution of the alcohol 3 (5.70 g, $22.1 \mathrm{mmol})$ in ethyl vinyl ether $(200 \mathrm{~mL})$ were added $\mathrm{Hg}(\mathrm{OAc})_{2}(94.0 \mathrm{mg}$, $221 \mu \mathrm{mol})$ and $\mathrm{Hg}\left(\mathrm{OCOCF}_{3}\right)_{2}(70.0 \mathrm{mg}, 221 \mu \mathrm{mol})$ at $\mathrm{rt}$, and then the mixture was stirred at $50{ }^{\circ} \mathrm{C}$ for $48 \mathrm{~h}$. After cooled to rt, the mixture was evaporated to furnish a crude product, which was chromatographed on silica gel (49: 1 hexane/EtOAc) affording 4 (5.22 g, 83\%) as colorless oil. IR (neat) v 2950, 2850, 1640, 1610, 1470, 1460, 1260, 1200, 1100, 840, $780 \mathrm{~cm}^{-1} ;{ }^{1} \mathrm{H}$ NMR $\left(\mathrm{CDCl}_{3}\right) \delta 6.24(\mathrm{dd}, J=14.0,6.6 \mathrm{~Hz}, 1 \mathrm{H}), 4.89-4.86(\mathrm{~m}, 2 \mathrm{H}), 4.25(\mathrm{dd}, J=14.0,1.4 \mathrm{~Hz}, 1 \mathrm{H})$, $4.03(\mathrm{t}, J=6.6 \mathrm{~Hz}, 1 \mathrm{H}), 3.93(\mathrm{dd}, J=6.6,1.4 \mathrm{~Hz}, 1 \mathrm{H}), 3.56(\mathrm{t}, J=6.6 \mathrm{~Hz}, 2 \mathrm{H}), 1.62(\mathrm{~s}, 3 \mathrm{H})$, $1.58-1.43(\mathrm{~m}, 4 \mathrm{H}), 1.21-1.41(\mathrm{~m}, 2 \mathrm{H}), 0.85(\mathrm{~s}, 9 \mathrm{H}), 0.00(\mathrm{~s}, 6 \mathrm{H}) ;{ }^{13} \mathrm{C} \mathrm{NMR}\left(\mathrm{CDCl}_{3}\right) \oint 150.8$, $144.4,113.4,88.7,83.9,63.1,33.0,32.6,25.9,21.8,18.3,16.8,-5.4$; LRMS m/z (rel intensity) 
$241\left(6, \mathrm{M}^{+}-\mathrm{C}_{2} \mathrm{H}_{3} \mathrm{O}\right), 227\left(10, \mathrm{M}^{+}-\mathrm{B} \mathrm{Bu}\right), 109$ (100). Anal. Calcd for $\mathrm{C}_{16} \mathrm{H}_{32} \mathrm{O}_{2} \mathrm{Si}$ : C, 67.54; $\mathrm{H}$, 11.33. Found: C, 67.65; H, 11.35.

$(1 Z, 5 E)-10$-tert-Butyldimethylsiloxy-1-iodo-5-methyl-1,5-decadiene (1). A solution of the vinyl ether $4(1.56 \mathrm{~g}, 5.50 \mathrm{mmol})$ in degassed benzene $(8 \mathrm{~mL})$ in a sealed tube was allowed to warm at $105{ }^{\circ} \mathrm{C}$ for $48 \mathrm{~h}$. After being cooled to rt, the mixture was evaporated to give the crude oil, which was used in the next step without purification. To a solution of $\mathrm{Ph}_{3} \mathrm{P}^{+} \mathrm{CH}_{2} \mathrm{I}\left(\mathrm{I}^{-}\right)(4.10 \mathrm{~g}$, $7.70 \mathrm{mmol})$ in THF $(45 \mathrm{~mL})$ at $-78^{\circ} \mathrm{C}$ was dropwise added NaHMDS (1.0 M in THF; $6.60 \mathrm{~mL}$, $5.66 \mathrm{mmol}$ ), and then the resulting solution was stirred at $-78{ }^{\circ} \mathrm{C}$ for $30 \mathrm{~min}$. After the slow addition of the solution of the above aldehyde in THF $(5 \mathrm{~mL})$, the mixture was stirred at $-78^{\circ} \mathrm{C}$ for $1 \mathrm{~h}$, and allowed to warn to rt. The mixture was diluted with hexane and filtered through Celite, and the residue was washed with hexane. The filtrate was washed with $\mathrm{H}_{2} \mathrm{O}$, brine, dried, filtered, and evaporated. Chromatography of the resulting oil on silica gel (49: 1 hexane/EtOAc) afforded $1(1.45 \mathrm{~g}, 62 \%)$ as colorless oil. IR (neat) $\vee 2920,2850,1460,1250$, $1100,830,770 \mathrm{~cm}^{-1} ;{ }^{1} \mathrm{H}-\mathrm{NMR}\left(\mathrm{CDCl}_{3}\right) \delta 6.19-6.13(\mathrm{~m}, 2 \mathrm{H}), 5.15(\mathrm{~m}, 1 \mathrm{H}), 3.61$ $(\mathrm{t}, J=6.4 \mathrm{~Hz}, 2 \mathrm{H}), 2.26-1.97(\mathrm{~m}, 6 \mathrm{H}), 1.62(\mathrm{~s}, 3 \mathrm{H}), 1.58-1.34(\mathrm{~m}, 4 \mathrm{H}), 0.90(\mathrm{~s}, 9 \mathrm{H}), 0.05$ $(\mathrm{s}, 6 \mathrm{H}) ;{ }^{13} \mathrm{C} \mathrm{NMR}\left(\mathrm{CDCl}_{3}\right) \delta 141.2,134.0,125.7,82.3,63.2,37.7,33.2,32.5,27.6,26.0,18.4$, 15.9, -5.3; LRMS m/z (rel intensity) 351 (51, $\mathrm{M}^{+}-\mathrm{B}$ ), 75 (100). HRMS calcd for $\mathrm{C}_{13} \mathrm{H}_{24} \mathrm{IOSi}$ $\left(\mathrm{M}^{+}-{ }^{\mathrm{t}} \mathrm{Bu}\right) 351.0639$, found 351.0639 .

(6E)-11-tert-Butyldimethylsiloxy-2,6-dimethyl-1,6-undecadien-3-ol (12). A solution of the vinyl ether $4(1.96 \mathrm{~g}, 6.88 \mathrm{mmol})$ in degassed benzene $(5 \mathrm{~mL})$ in a sealed tube was allowed to warm at $105{ }^{\circ} \mathrm{C}$ for $48 \mathrm{~h}$. After being cooled to $\mathrm{rt}$, the solution was concentrated under reduced pressure to furnish the residue, which was used in the next step without purification. To a suspension of $\mathrm{Li}(239 \mathrm{mg}, 34.4 \mathrm{mmol})$ in $\mathrm{Et}_{2} \mathrm{O}(70 \mathrm{~mL})$ was added 2-bromopropene $(0.92 \mathrm{~mL}$, $10.3 \mathrm{mmol})$ in $\mathrm{Et}_{2} \mathrm{O}(3 \mathrm{~mL})$ at $0{ }^{\circ} \mathrm{C}$, and then the mixture was irradiated of an ultrasonic cleaner at $0{ }^{\circ} \mathrm{C}$ for $1 \mathrm{~h}$. After the slow addition of the above aldehyde in $\mathrm{Et}_{2} \mathrm{O}(10 \mathrm{~mL})$ at $0{ }^{\circ} \mathrm{C}$, the resulting mixture was irradiated at the same temperature for $10 \mathrm{~min}$. The reaction solution was quenched with sat. $\mathrm{NH}_{4} \mathrm{Cl}$ at $0{ }^{\circ} \mathrm{C}$, and then extracted with $\mathrm{Et}_{2} \mathrm{O}$. The organic extracts were washed with brine, dried, filtered, and evaporated to give crude residue, which was chromatographed on silica gel (19: 1 hexane/EtOAc) to provide 12 (2.22 g, 99\% from 4) as colorless oil. IR (neat) v 3650-3150, 2950, 2860, 1480, 1470, 1390, 1260, 1100, 840, $780 \mathrm{~cm}^{-1}$; ${ }^{1} \mathrm{H}$ NMR $\left(\mathrm{CDCl}_{3}\right) \delta 5.13(\mathrm{t}, J=7.0 \mathrm{~Hz}, 1 \mathrm{H}), 4.90(\mathrm{~m}, 1 \mathrm{H}), 4.80(\mathrm{~s}, 1 \mathrm{H}), 4.01(\mathrm{~s}, 1 \mathrm{H}), 3.56(\mathrm{t}, J=$ $6.3 \mathrm{~Hz}, 2 \mathrm{H}), 2.05-1.90(\mathrm{~m}, 4 \mathrm{H}), 1.69(\mathrm{~s}, 3 \mathrm{H}), 1.57(\mathrm{~s}, 3 \mathrm{H}), 1.65-1.43(\mathrm{~m}, 5 \mathrm{H}), 1.37-1.29(\mathrm{~m}$, $2 \mathrm{H}), 0.85(\mathrm{~s}, 9 \mathrm{H}), 0.00(\mathrm{~s}, 6 \mathrm{H}) ;{ }^{13} \mathrm{C} \mathrm{NMR}\left(\mathrm{CDCl}_{3}\right) \delta 147.7,134.9,125.2,111.2,75.8,63.2,35.7$, 33.2, 32.5, 27.7, 26.0, 18.4, 17.6, 16.0, -5.32; LRMS m/z (rel intensity) $269\left(3, \mathrm{M}^{+}-{ }^{\mathrm{t}} \mathrm{Bu}\right), 75$ (100). Anal. Calcd for $\mathrm{C}_{19} \mathrm{H}_{38} \mathrm{O}_{2} \mathrm{Si}$ : C, 69.88; H, 11.73. Found: C, 70.07; H, 11.55.

(6E)-11-tert-Butyldimethylsiloxy-2,6-dimethyl-3-vinyloxy-1,6-undecadiene (13). To a stirred solution of the alcohol $12(5.00 \mathrm{~g}, 15.3 \mathrm{mmol})$ in ethyl vinyl ether $(115 \mathrm{~mL})$ were added $\mathrm{Hg}(\mathrm{OAc})_{2}(49.0 \mathrm{mg}, 150 \mu \mathrm{mol})$ and $\mathrm{Hg}\left(\mathrm{OCOCF}_{3}\right)_{2}(65.0 \mathrm{mg}, 150 \mu \mathrm{mol})$ at $\mathrm{rt}$, and then the mixture was stirred at $50{ }^{\circ} \mathrm{C}$ for $48 \mathrm{~h}$. After being cooled to $\mathrm{rt}$, the mixture was evaporated to give an oily residue, which was purified by chromatography on silica gel (49: 1 hexane/EtOAc) 
giving 13 (5.27 g, 98\%) as colorless oil. IR (neat) $\vee$ 2940, 2860, 1640, 1480, 1460, 1260, 1200, $1170,1100,840,780 \mathrm{~cm}^{-1} ;{ }^{1} \mathrm{H}$ NMR $\left(\mathrm{CDCl}_{3}\right) \delta 6.27(\mathrm{dd}, J=14.0,6.6 \mathrm{~Hz}, 1 \mathrm{H}), 5.14(\mathrm{t}, J=6.0$ $\mathrm{Hz}, 1 \mathrm{H}), 4.93-4.90(\mathrm{~m}, 2 \mathrm{H}), 4.29(\mathrm{dd}, J=14.0,1.4 \mathrm{~Hz}, 1 \mathrm{H}), 4.05(\mathrm{t}, J=6.6 \mathrm{~Hz}, 1 \mathrm{H}), 3.97$ (dd, $J$ $=6.6,1.4 \mathrm{~Hz}, 1 \mathrm{H}), 3.60(\mathrm{t}, J=6.3 \mathrm{~Hz}, 2 \mathrm{H}), 2.06-1.94(\mathrm{~m}, 5 \mathrm{H}), 1.83-1.71(\mathrm{~m}, 1 \mathrm{H}), 1.67(\mathrm{~s}, 3 \mathrm{H})$, $1.59(\mathrm{~s}, 3 \mathrm{H}), 1.57-1.47(\mathrm{~m}, 2 \mathrm{H}), 1.40-1.31(\mathrm{~m}, 2 \mathrm{H}), 0.89(\mathrm{~s}, 9 \mathrm{H}), 0.00(\mathrm{~s}, 6 \mathrm{H})$; ${ }^{13} \mathrm{C} \mathrm{NMR}$ $\left(\mathrm{CDCl}_{3}\right) \delta 150.8,144.5,134.3,125.4,113.4,88.7,83.3,63.2,35.4,32.5,31.7,27.7,26.0,26.0$, 26.0, 18.4, 16.9, 16.0, -5.3; LRMS m/z (rel intensity) $309\left(1, \mathrm{M}^{+}-\mathrm{C}_{2} \mathrm{H}_{3} \mathrm{O}\right), 295\left(2, \mathrm{M}^{+}-\mathrm{Bu}\right), 43$ (100). Anal. Calcd for $\mathrm{C}_{21} \mathrm{H}_{40} \mathrm{O}_{2} \mathrm{Si}: \mathrm{C}, 71.53 ; \mathrm{H}, 11.43$. Found: $\mathrm{C}, 71.50 ; \mathrm{H}, 11.28$.

(5E,9E,13Z)-14-Iodo-6,10-dimethyl-5,9,13-tetradecatrien-1-ol (14). A solution of the vinyl ether 13 (1.66 g, $4.72 \mathrm{mmol})$ in degassed benzene $(2 \mathrm{~mL})$ in a sealed tube was allowed to warm at $105{ }^{\circ} \mathrm{C}$ for $24 \mathrm{~h}$. After being cooled to rt, the mixture was evaporated to give crude residue, which was used in the next step without purification. To a solution of $\mathrm{Ph}_{3} \mathrm{P}^{+} \mathrm{CH}_{2} \mathrm{I}\left(\mathrm{I}^{-}\right)(3.50 \mathrm{~g}$, $6.61 \mathrm{mmol})$ in THF $(70 \mathrm{~mL})$ at $-78^{\circ} \mathrm{C}$ was added dropwise NaHMDS (1.0 M in THF; $5.66 \mathrm{~mL}$, $5.66 \mathrm{mmol}$ ), and then the resulting solution was stirred at $-78{ }^{\circ} \mathrm{C}$ for $0.5 \mathrm{~h}$. After the slow addition of the solution of the above aldehyde in THF $(8 \mathrm{~mL})$, the mixture was stirred at $-78{ }^{\circ} \mathrm{C}$ for $1 \mathrm{~h}$, and allowed to warm to rt. The mixture was diluted with hexane and filtered through Celite. The filtrate was washed with $\mathrm{H}_{2} \mathrm{O}$, brine, dried, filtered, and evaporated to give oily residue, which was used in the next step without purification. To a solution of the above Z-olefin in THF $(5 \mathrm{~mL})$ was added a mixture of $\mathrm{AcOH}$ and $\mathrm{H}_{2} \mathrm{O}(3: 1 \mathrm{v} / \mathrm{v}, 20 \mathrm{~mL})$ at $0{ }^{\circ} \mathrm{C}$, and the resulting mixture was stirred at $0{ }^{\circ} \mathrm{C}$ for $48 \mathrm{~h}$. The mixture was quenched with sat. $\mathrm{NaHCO}_{3}$, and then extracted with EtOAc. The organic layers were washed with brine, dried, filtered. Removal of the solvent under reduced pressure followed by chromatography on silica gel (4: 1 hexane/EtOAc) afforded 14 (1.28 g, 75\% from 13) as colorless oil. IR (neat) v 3600-3100, 2930, 2850, 1450, 1300, 1280, $1060 \mathrm{~cm}^{-1} ;{ }^{1} \mathrm{H}$ NMR $\left(\mathrm{CDCl}_{3}\right) \delta 6.19-6.10(\mathrm{~m}, 2 \mathrm{H}), 5.13(\mathrm{t}, J=6.9 \mathrm{~Hz}$, $2 \mathrm{H}), 3.64(\mathrm{t}, J=6.3 \mathrm{~Hz}, 2 \mathrm{H}), 2.27-2.20(\mathrm{~m}, 2 \mathrm{H}), 2.15-2.00(\mathrm{~m}, 9 \mathrm{H}), 1.62(\mathrm{~s}, 3 \mathrm{H}), 1.60(\mathrm{~s}, 3 \mathrm{H})$, 1.58-1.53 (m, 2H), 1.45-1.35 (m, 2H); LRMS m/z (rel intensity) 362 (4), 71 (100). HRMS calcd for $\mathrm{C}_{16} \mathrm{H}_{27} \mathrm{IO}\left(\mathrm{M}^{+}\right)$362.1104, found 362.1109.

Methyl (2E,7E,11E,15Z)-16-iodo-8,12-dimethyl-2,7,11,15-hexadecatetraenoate (10). To a stirred suspension of Dess-Martin periodinane $(8.17 \mathrm{~g}, 19.3 \mathrm{mmol})$ in $\mathrm{CH}_{2} \mathrm{Cl}_{2}(50 \mathrm{~mL})$ was added $14(1.99 \mathrm{~g}, 5.5 \mathrm{mmol})$ in $\mathrm{CH}_{2} \mathrm{Cl}_{2}(10 \mathrm{~mL})$ at $\mathrm{rt}$ for $2 \mathrm{~h}$. The resulting mixture was diluted with $\mathrm{Et}_{2} \mathrm{O}$, and then quenched with sat. $\mathrm{NaHCO}_{3}$ and $0.1 \mathrm{~N} \mathrm{Na}_{2} \mathrm{~S}_{2} \mathrm{O}_{3}$, and stirred for an additional hour. The solution was extracted with $\mathrm{Et}_{2} \mathrm{O}$, and the ethereal layers were washed with sat. $\mathrm{NaHCO}_{3}$ and brine, dried, filtered, and evaporated to furnish the crude aldehyde, which was used in the next step without further purification. To a stirred suspension of $\mathrm{NaH}(60 \% \mathrm{w} / \mathrm{w}$ in oil; $441 \mathrm{mg}, 11.0 \mathrm{mmol})$ in DME $(100 \mathrm{~mL})$ was added trimethylphosphonoacetate $(2.23 \mathrm{ml}$, $13.8 \mathrm{mmol}$ ) at $\mathrm{rt}$ and stirred for $30 \mathrm{~min}$. After the slow addition of the above aldehyde in DME $(10 \mathrm{~mL})$, the resulting mixture was stirred at the same temperature for $3 \mathrm{~h}$. The mixture was quenched with $\mathrm{H}_{2} \mathrm{O}$, and the solution was extracted with $\mathrm{Et}_{2} \mathrm{O}$. The ethereal layers were washed with $\mathrm{H}_{2} \mathrm{O}$, brine, dried, filtered, and evaporated. Chromatography of the resultant oil on silica gel (97: 3 hexane/EtOAc) afforded 10 (1.70 g, 74\% from 14) as colorless oil. IR (neat) $\vee 2930,2850$, 
1720, 1660, 1440, 1280, $1200 \mathrm{~cm}^{-1} ;{ }^{1} \mathrm{H}$ NMR $\left(\mathrm{CDCl}_{3}\right) \delta 6.98(\mathrm{dt}, J=15.7,7.0 \mathrm{~Hz}, 1 \mathrm{H}), 6.19-$ $6.10(\mathrm{~m}, 2 \mathrm{H}), 5.82(\mathrm{~d}, J=15.7 \mathrm{~Hz}, 1 \mathrm{H}), 5.15-5.10(\mathrm{~m}, 2 \mathrm{H}), 3.73(\mathrm{~s}, 3 \mathrm{H}), 2.27-1.98(\mathrm{~m}, 12 \mathrm{H})$, $1.63(\mathrm{~s}, 3 \mathrm{H}), 1.59(\mathrm{~s}, 3 \mathrm{H}), 1.55-1.46(\mathrm{~m}, 2 \mathrm{H}) ;{ }^{13} \mathrm{C} \mathrm{NMR}\left(\mathrm{CDCl}_{3}\right) \quad \delta 167.3,149.8,141.1$, $135.8,133.9,125.2,123.9,121.0,82.2,51.3,39.5,37.6,33.2,31.6,28.0,27.2,26.4,15.9,15.8$; LRMS m/z (rel intensity) 416 (1), 108 (100). HRMS calcd for $\mathrm{C}_{19} \mathrm{H}_{29} \mathrm{I} \mathrm{O}_{2}\left(\mathrm{M}^{+}\right) 416.1210$, found 416.1224 .

Dimethyl (6E)-2,6-dimethylnona-2,6-diene-9,9-dicarboxylate (15). To a stirred suspension of $\mathrm{NaH}$ (1.15 g, 60\% in oil, $28.8 \mathrm{mmol})$ in dry THF $(150 \mathrm{~mL})$ was added dimethyl malonate $(3.47 \mathrm{~g}$, $26.3 \mathrm{mmol})$ in dry THF $(30 \mathrm{~mL})$ dropwise at $0{ }^{\circ} \mathrm{C}$. After being stirred for $15 \mathrm{~min}$, a solution of geranyl bromide $(5.70 \mathrm{~g}, 26.3 \mathrm{mmol})$ in dry THF $(20 \mathrm{~mL})$ was added to the reaction mixture at the same temperature. The reaction mixture was stirred for additional $45 \mathrm{~min}$. The mixture was quenched with $\mathrm{H}_{2} \mathrm{O}$, and then extracted with $\mathrm{Et}_{2} \mathrm{O}$. The organic layer was washed with $10 \% \mathrm{HCl}$, $\mathrm{NaHCO}_{3}$ solution and brine, dried $\left(\mathrm{MgSO}_{4}\right)$, evaporated to give oily residue. The crude oil was purified by column chromatography on silica gel (9: 1 hexane/EtOAc) to afforded 15 (5.00 g, $71 \%$ ) as colorless oil. IR (neat) $v 2948,2928,1735,1429,1150 \mathrm{~cm}^{-1} ;{ }^{1} \mathrm{H} \mathrm{NMR}\left(\mathrm{CDCl}_{3}\right) \delta 5.07$ (br s, 2H), $3.73(\mathrm{~s}, 6 \mathrm{H}), 3.38(\mathrm{t}, J=7.7 \mathrm{~Hz}, 1 \mathrm{H}), 2.61(\mathrm{t}, J=7.7 \mathrm{~Hz}, 2 \mathrm{H}), 2.06-1.94(\mathrm{~m}, 4 \mathrm{H})$, $1.67(\mathrm{~s}, 3 \mathrm{H}), 1.63(\mathrm{~s}, 3 \mathrm{H}), 1.59(\mathrm{~s}, 3 \mathrm{H}) ;{ }^{13} \mathrm{C} \mathrm{NMR}\left(\mathrm{CDCl}_{3}\right) \delta 169.7,138.8,131.5,124.1,119.5$, 52.3, 51.8, 39.6, 27.4, 26.4, 25.5, 17.5, 15.8; LRMS m/z $268\left(\mathrm{M}^{+}\right), 225,199,167,136,107,69$; Anal. Calcd for $\mathrm{C}_{15} \mathrm{H}_{24} \mathrm{O}_{4}$ : C, 67.14; H, 9.01\%. Found: C, 66.72; H, 9.04\%.

Trimethyl (6E,11E)-2,6-dimethyldodeca-2,6,11-triene-9,9,12-tricarboxylate (16). To a suspension of $\mathrm{NaH}(0.48 \mathrm{~g}, 60 \%$ in oil, $12.1 \mathrm{mmol})$ in dry THF $(100 \mathrm{~mL})$, was added diester 15 $(3.00 \mathrm{~g}, 11.19 \mathrm{mmol})$ in dry THF $(15 \mathrm{~mL})$ dropwise at $0{ }^{\circ} \mathrm{C}$, and stirred for $20 \mathrm{~min}$. To the reaction mixture was added a solution of methyl 4-bromocrotonate $(1.5 \mathrm{~mL}, 12.8 \mathrm{mmol})$ in dry THF $(10 \mathrm{~mL})$ at the same temperature. After being stirred for $1 \mathrm{~h}, \mathrm{H}_{2} \mathrm{O}$ was added into the reaction mixture. The mixture was extracted with $\mathrm{Et}_{2} \mathrm{O}$, washed with $10 \% \mathrm{HCl}, \mathrm{NaHCO}_{3}$ solution and brine, dried and concentrated. The crude oil was purified by column chromatography on silica gel (4: 1 hexane/EtOAc) to afford 16 (3.77 g, 92\%) as colorless. IR (neat) v 2950, 2851, 1735, 1721, 1649, $1436 \mathrm{~cm}^{-1} ;{ }^{1} \mathrm{H} \mathrm{NMR}\left(\mathrm{CDCl}_{3}\right) \delta 6.79(\mathrm{dt}, J=15.5,7.7 \mathrm{~Hz}$, $1 \mathrm{H}), 5.84(\mathrm{dt}, J=15.5,1.4 \mathrm{~Hz}, 1 \mathrm{H}), 5.01-4.90(\mathrm{~m}, 2 \mathrm{H}), 3.76(\mathrm{~s}, 9 \mathrm{H}), 2.75$ (dd, $J=7.7,1.4 \mathrm{~Hz}$, 2H), $2.63(\mathrm{~d}, J=7.7 \mathrm{~Hz}, 2 \mathrm{H}), 2.16-1.98(\mathrm{~m}, 4 \mathrm{H}), 1.68(\mathrm{~s}, 3 \mathrm{H}), 1.60(\mathrm{~s}, 6 \mathrm{H}) ;{ }^{13} \mathrm{C} \mathrm{NMR}\left(\mathrm{CDCl}_{3}\right) \delta$ 171.2, 166.5, 143.4, 140.1, 131.8, 124.7, 124.1, 117.2, 57.6, 52.6, 51.5, 39.9, 35.3, 31.4, 26.4, 25.6, 17.7, 16.2; LRMS m/z $366\left(\mathrm{M}^{+}\right)$, 334, 306, 237, 205, 145, 69; HRMS calcd for $\mathrm{C}_{20} \mathrm{H}_{30} \mathrm{O}_{6}$ : 366.2042. Found: 366.2036.

Trimethyl (3E,8E)-1-formyl-3-methylnona-3,8-diene-6,6,9-tricarboxylate (17). To a solution of the triester $16(3.00 \mathrm{~g}, 8.2 \mathrm{mmol})$ in $\mathrm{CH}_{3} \mathrm{CN}-\mathrm{H}_{2} \mathrm{O}(2: 1 ; 75 \mathrm{~mL})$ was added $N$ methylmorpholine oxide $(1.92 \mathrm{~g}, 16.4 \mathrm{mmol})$ and catalytic amount of $\mathrm{OsO}_{4}(1 \mathrm{~mL}, 1 \% \mathrm{w} / \mathrm{v}$ in THF) at $0{ }^{\circ} \mathrm{C}$. The mixture was stirred for $8 \mathrm{~h}$ at room temperature. A saturated solution of $\mathrm{Na}_{2} \mathrm{SO}_{3}$ was added into the reaction mixture. After being stirred for $2 \mathrm{~h}$, the reaction mixture was diluted with EtOAc. The mixture was extracted with EtOAc, washed with $10 \% \mathrm{HCl}, \mathrm{NaHCO}_{3}$ solution and brine, dried and concentrated. The crude oil was purified by column 
chromatography on silica gel (1: 1 hexane/EtOAc) to afford the corresponding diol $(2.79 \mathrm{~g}$, $85 \%$ ) as colorless oil. Diol; IR (neat) $v$ 3448, 2951, 1735,1722,1650, $1435 \mathrm{~cm}^{-1}$; ${ }^{1} \mathrm{H}$ NMR $\left(\mathrm{CDCl}_{3}\right) \delta 6.80(\mathrm{dt}, J=15.4,7.7 \mathrm{~Hz}, 1 \mathrm{H}), 5.86(\mathrm{dt}, J=15.4,1.4 \mathrm{~Hz}, 1 \mathrm{H}), 5.05(\mathrm{t}, J=7.1 \mathrm{~Hz}, 1 \mathrm{H})$, $3.73(\mathrm{~s}, 6 \mathrm{H}), 3.72(\mathrm{~s}, 3 \mathrm{H}), 3.30(\mathrm{br} \mathrm{d}, J=10.4 \mathrm{~Hz}, 1 \mathrm{H}), 2.77(\mathrm{~d}, J=7.7 \mathrm{~Hz}, 2 \mathrm{H}), 2.63(\mathrm{~d}, J=7.7$ $\mathrm{Hz}, 2 \mathrm{H}), 2.36$ (br s, 1H), 2.29-2.05 (m, 3H), 1.79 (br s, 1H), 1.61 (s, 3H), 1.46-1.33 (m, 1H), $1.20(\mathrm{~s}, 3 \mathrm{H}), 1.16(\mathrm{~s}, 3 \mathrm{H}) ;{ }^{13} \mathrm{C} \mathrm{NMR}\left(\mathrm{CDCl}_{3}\right) \delta 171.2,166.5,143.2,139.8,124.6,117.6,77.7$, 72.9, 57.5, 52.6, 51.5, 36.8, 35.3, 31.4, 29.4, 26.2, 23.2, 16.0; LRMS m/z $382\left(\mathrm{M}^{+}-\mathrm{H}_{2} \mathrm{O}\right), 351$, 341, 299, 251, 237, 198, 166, 59.

To a solution of the above diol $(3.60 \mathrm{~g}, 9.00 \mathrm{mmol})$ in $\mathrm{Et}_{2} \mathrm{O}-\mathrm{H}_{2} \mathrm{O}(2: 1)$ (100 mL) was added $\mathrm{NaIO}_{4}(2.30 \mathrm{~g}, 10.8 \mathrm{mmol})$ at room temperature. After being stirred for $2 \mathrm{~h}$, the reaction mixture was diluted with $\mathrm{Et}_{2} \mathrm{O}$, and then extracted with $\mathrm{Et}_{2} \mathrm{O}$. The mixture was washed with brine, dried and evaporated. The crude oil was purified by column chromatography on silica gel (4: 1 hexane/EtOAc) to afford 17 (3.00 g, 98\%) as colorless oil. IR (neat) $\vee 2936,1735,1720,1648$, $1426 \mathrm{~cm}^{-1} ;{ }^{1} \mathrm{H} \mathrm{NMR}\left(\mathrm{CDCl}_{3}\right) \delta 9.75(\mathrm{t}, J=1.8 \mathrm{H}, 1 \mathrm{H}), 6.77(\mathrm{dt}, J=15.4,7.7 \mathrm{~Hz}, 1 \mathrm{H}), 5.85(\mathrm{dt}, J$ $=15.4,1.4 \mathrm{~Hz}, 1 \mathrm{H}), 5.04-4.99(\mathrm{~m}, 1 \mathrm{H}), 3.73(\mathrm{~s}, 6 \mathrm{H}), 3.72(\mathrm{~s}, 3 \mathrm{H}), 2.74(\mathrm{dd}, J=7.7,1.4 \mathrm{~Hz}, 2 \mathrm{H})$, $2.62(\mathrm{~d}, J=7.4 \mathrm{~Hz}, 2 \mathrm{H}), 2.54-2.49(\mathrm{~m}, 2 \mathrm{H}), 2.33(\mathrm{t}, J=7.7 \mathrm{~Hz}, 2 \mathrm{H}), 1.62(\mathrm{~s}, 3 \mathrm{H}) ;{ }^{13} \mathrm{C}$ NMR $\left(\mathrm{CDCl}_{3}\right) \delta 202.2,171.1,166.5,143.0,138.2,124.8,118.4,57.5,52.7,51.6,42.1,35.5,32.0,31.4$, 16.3; LRMS m/z $341\left(\mathrm{M}^{+}+1\right), 308,277,258,226,198,177,166$; Anal. Calcd for $\mathrm{C}_{17} \mathrm{H}_{24} \mathrm{O}_{7}$ : C, 59.99; H, 7.11\%. Found: C, 59.65; H, 7.01\%.

Trimethyl (1Z,5E,10E)-1-Iodo-5-methylundeca-1,5-10-triene-8,8,11-tricarboxylate (11). To a solution of (iodomethyl)triphenylphosphonium iodide $\left[\mathrm{Ph}_{3} \mathrm{P}^{+} \mathrm{CH}_{2} \mathrm{I}\left(\mathrm{I}^{-}\right)\right](7.03 \mathrm{~g}, 13.3 \mathrm{mmol})$ in THF $(60 \mathrm{~mL})$ was added $1.5 \mathrm{M}$ hexane-solution of sodium hexamethyldisilazide (NaHMDS; $10 \mathrm{~mL}, 15 \mathrm{mmol}$ ) at room temperature, and then the mixture was stirred for $2 \mathrm{~h}$ at the same temperature. To the resulting mixture was added a solution of $\mathbf{1 7}$ (2.25 g, $6.62 \mathrm{mmol})$ in THF $(5 \mathrm{~mL})$ at $-78{ }^{\circ} \mathrm{C}$. The mixture was stirred for $20 \mathrm{~min}$ at $-78^{\circ} \mathrm{C}$, and then diluted with hexane. After filtration through Celite and rinse with hexane, the organic layer was washed with brine, and then dried. The residue was purified with column chromatography on silica gel (1: 9 EtOAc/hexane) to give 11 (1.70 g, 57\%) as colorless oil. IR (neat) $\vee 2950,1735,1725,1649$, $1437 \mathrm{~cm}^{-1} ;{ }^{1} \mathrm{H}$ NMR $\left(\mathrm{CDCl}_{3}\right) \delta 6.79(\mathrm{dt}, J=15.4,7.7 \mathrm{~Hz}, 1 \mathrm{H}), 6.21(\mathrm{dt}, J=7.4,1.3 \mathrm{~Hz}, 1 \mathrm{H})$, $6.11(\mathrm{q}, J=6.3 \mathrm{~Hz}, 1 \mathrm{H}), 5.86(\mathrm{dt}, J=15.4,1.4 \mathrm{~Hz}, 1 \mathrm{H}), 5.00-4.95(\mathrm{~m}, 1 \mathrm{H}), 3.76(\mathrm{dd}, J=7.7,1.3$ $\mathrm{Hz}, 2 \mathrm{H}), 3.73$ (s, 6H), 2.63 (d, $J=7.4 \mathrm{~Hz}, 2 \mathrm{H}), 2.27-2.20(\mathrm{~m}, 2 \mathrm{H}), 2.21$ (t, $J=7.1 \mathrm{~Hz}, 2 \mathrm{H}), 1.63$ $(\mathrm{s}, 3 \mathrm{H}) ;{ }^{13} \mathrm{C} \mathrm{NMR}\left(\mathrm{CDCl}_{3}\right) \delta 171.0,166.3,143.1,140.6,138.9,124.7,118.0,82.7,57.4,52.6$, 51.5, 37.8, 35.3, 33.0, 31.3, 16.1; MS m/z $465\left(\mathrm{M}^{+}+1\right)$; HRMS $m / z$ calcd for $\mathrm{C}_{19} \mathrm{H}_{26} \mathrm{IO}_{6}\left(\mathrm{M}^{+}+1\right)$ 465.0774, found 465.0797 .

\section{General procedure of radical reaction. (for TBTH and TTMSH methods)}

To a stirred solution of the vinyl iodide $(0.10 \mathrm{mmol})$ in degassed benzene or toluene $(1 \sim 2 \mathrm{mM})$ was added a $1 \mathrm{M}$ solution of $\mathrm{Et}_{3} \mathrm{~B}$ in hexane $(50 \mu \mathrm{L}, 0.05 \mathrm{mmol})$ or $\mathrm{AIBN}(8.5 \mathrm{mg}, 0.05 \mathrm{mmol})$ at room temperature. To the mixture was slowly added a solution of $\mathrm{Bu}_{3} \mathrm{SnH}(30 \mu \mathrm{L}, 0.12 \mathrm{mmol})$ or $(\mathrm{TMS})_{3} \mathrm{SiH}(40 \mu \mathrm{L}, 0.12 \mathrm{mmol})$ in degassed benzene $(5 \mathrm{~mL})$ over $3 \mathrm{~h}$ using a syringe pump. 
After being stirred, the solution was concentrated. The resulting residue was chromatographed on silica gel.

(for indirected electrolysis) The radical cyclization of the iodides (1.0 equiv.) by electroreductively generated nickel(I) species was carried out in DMF (13 mL) containing supporting electrolyte $\left(\mathrm{Et}_{4} \mathrm{NClO}_{4} ; 0.1 \mathrm{M}\right.$ in $\left.\mathrm{DMF}\right)$, proton source $\left(\mathrm{NH}_{4} \mathrm{ClO}_{4}, 2\right.$ equiv. based onthe iodide), and catalytic amount of the nickel(II) complex (0.1 equiv based on the iodide) potentiostatically at the reductive peak potential of the nickel(II) complex using a graphite electrode as the cathode in an H-shaped divided cell under inert gas with mechanical stirring. Electrolysis of the iodides was carried out at $-1.50 \mathrm{~V}$ vs. SCE. After all the iodide was consumed by electrolysis, the catholyte was subjected to the usual extractive work up followed by purification on silica gel column chromatography.

1-(5-Hydroxypentyl)-1-methyl-2-cyclopentene (5b) and 1-(4-Hydroxybutyl)-6-methyl-2cyclohexene (6b). (Table 1, entry 1) Radical reaction was carried out by TBTH method at $40{ }^{\circ} \mathrm{C}$ to give crude mixture of silyl ethers $5 \mathbf{a}$ and $\mathbf{6 a}$. To a solution of the above silyl ethers in THF $(1 \mathrm{~mL})$ was added a mixture of $\mathrm{AcOH}$ and $\mathrm{H}_{2} \mathrm{O}(3: 1 \mathrm{v} / \mathrm{v}, 4 \mathrm{~mL})$ at $0{ }^{\circ} \mathrm{C}$, and the resulting mixture was stirred at $0{ }^{\circ} \mathrm{C}$ for $24 \mathrm{~h}$. The mixture was quenched with sat. $\mathrm{NaHCO}_{3}$ and the resulting solution was extracted with EtOAc. The organic extracts were washed with brine, dried, and filtered. Removal of the solvent under reduced pressure followed by chromatography on silica gel (4: 1 hexane/EtOAc) provided alcohols $5 \mathbf{b}$ and $\mathbf{6 b}(22.0 \mathrm{mg}, 70 \%$ from $\mathbf{1})$ as an inseparable $2: 1$ mixture. As a 2: 1 mixture; IR (neat) v 3600-3100, 2900, 2850, 1450, 1050, $740 \mathrm{~cm}^{-1} ;{ }^{1} \mathrm{H}$ NMR $\left(\mathrm{CDCl}_{3}\right) \delta$ 5.61-5.47 (m, 2H), 3.68-3.61 (m, 2H), 2.35-2.28 (m, 1H), 2.09$1.99(\mathrm{~m}, 2 \mathrm{H}), 1.75-1.26(\mathrm{~m}, 10 \mathrm{H}), 1.01(\mathrm{~s}, 2 \mathrm{H}), 0.96(\mathrm{~d}, J=6.6 \mathrm{~Hz}, 0.3 \mathrm{H}), 0.85(\mathrm{~d}, J=6.9 \mathrm{~Hz}$, $0.7 \mathrm{H}$ ); LRMS m/z (rel intensity) 168 (8), 81 (100). HRMS calcd for $\mathrm{C}_{11} \mathrm{H}_{20} \mathrm{O}\left(\mathrm{M}^{+}\right) 168.1513$, found 168.1505 .

1-(4-Hydroxybutyl)-6-methyl-2-cyclohexene (6b). (Table1, entry 2) As a $2: 1$ diastereomeric mixture; Colorless oil, IR (neat) v 3330, 2920, 2850, 1450, 1370, $1050 \mathrm{~cm}^{-1} ;{ }^{1} \mathrm{H} \mathrm{NMR}\left(\mathrm{CDCl}_{3}\right) \delta$ $5.65-5.51(\mathrm{~m}, 2 \mathrm{H}), 3.66(\mathrm{t}, J=6.6 \mathrm{~Hz}, 2 \mathrm{H}), 2.00-1.97(\mathrm{~m}, 3 \mathrm{H}), 1.61-1.26(\mathrm{~m}, 10 \mathrm{H}), 0.96(\mathrm{~d}, J=$ $6.6 \mathrm{~Hz}, 0.66 \mathrm{H}), 0.85$ (d, $J=6.9 \mathrm{~Hz}, 2.34 \mathrm{H})$; LRMS m/z (rel intensity) 168 (19), 95 (100). HRMS calcd for $\mathrm{C}_{11} \mathrm{H}_{20} \mathrm{O}\left(\mathrm{M}^{+}\right)$168.1513, found 168.1513.

11-Methoxycarbonylmethyl-2,10-dimethyltricyclo[8.4.0.0 $\left.{ }^{2,7}\right]$ tetradec-5-ene (18). Purified by Chromatography on silica gel (49: 1 hexane/EtOAc). As a 4: 4: 1: 1 diastereomeric mixture; Colorless oil, IR (neat) v 2950, 2870, 1720, 1600, $1440 \mathrm{~cm}^{-1} ;{ }^{1} \mathrm{H}$ NMR $\left(\mathrm{CDCl}_{3}\right) \delta 5.72-5.68(\mathrm{~m}$, $0.6 \mathrm{H}), 5.57-5.55(\mathrm{~m}, 0.8 \mathrm{H}), 5.36-5.32(\mathrm{~m}, 0.6 \mathrm{H}), 3.67(\mathrm{~s}, 0.3 \mathrm{H}), 3.66(\mathrm{~s}, 0.3 \mathrm{H}), 3.65(\mathrm{~s}, 1.2 \mathrm{H})$, 3.65 (s, 1.2H), 2.46-0.82 (m, 25H); LRMS m/z (rel intensity) 290 (94), 108 (100). HRMS calcd for $\mathrm{C}_{19} \mathrm{H}_{30} \mathrm{O}_{2}\left(\mathrm{M}^{+}\right)$290.2244, found 290.2242.

Methyl (2E,7E)-8-Methyl-11-(1-methyl-2-cyclopentenyl)-2,7-undecadienoate (19). Purified by Chromatography on silica gel (97: 3 hexane/EtOAc). Colorless oil. IR (neat) v 2920, 2850, 1720, 1650, 1450, 1430, 1260, 1200, $1160 \mathrm{~cm}^{-1} ;{ }^{1} \mathrm{H} \mathrm{NMR}\left(\mathrm{CDCl}_{3}\right) \delta 6.98(\mathrm{dt}, J=15.7,7.0 \mathrm{~Hz}$, $1 \mathrm{H}), 5.82(\mathrm{dt}, J=15.7,1.5 \mathrm{~Hz}, 1 \mathrm{H}), 5.59$ (dt, $J=5.5,2.2 \mathrm{~Hz}, 1 \mathrm{H}), 5.49$ (dt, $J=5.5,2.2 \mathrm{~Hz}, 1 \mathrm{H})$, $5.08(\mathrm{~m}, 1 \mathrm{H}), 3.73(\mathrm{~s}, 3 \mathrm{H}), 2.35-2.29(\mathrm{~m}, 2 \mathrm{H}), 2.37-2.16(\mathrm{~m}, 2 \mathrm{H}), 2.05-1.92(\mathrm{~m}, 4 \mathrm{H}), 1.72-1.61$ 
$(\mathrm{m}, 2 \mathrm{H}), 1.60(\mathrm{~s}, 3 \mathrm{H}), 1.57-1.26(\mathrm{~m}, 6 \mathrm{H}), 1.01(\mathrm{~s}, 3 \mathrm{H})$; LRMS m/z (rel intensity) 290 (3), 81 (100). HRMS calcd for $\mathrm{C}_{19} \mathrm{H}_{30} \mathrm{O}_{2}\left(\mathrm{M}^{+}\right)$290.2244, found 290.2241.

Trimethyl (1R $\left.{ }^{*}, 2 \mathrm{R}^{*}, 6 \mathrm{~S}^{*}, 7 \mathrm{~S}^{*}, 8 \mathrm{~S}^{*}\right)-1$-methyltricyclo[6.3.0.0 $\left.{ }^{2,6}\right]$ undecane-4,4,7-tricarboxylate $\left(\mathbf{2 0}^{\mathrm{a}}\right)$. Colorless oil, IR (neat) $v$ 2952, 2867, 1732, 1435, 1265, $1199 \mathrm{~cm}^{-1}$; 1H NMR (500 MHz, $\left.\mathrm{CDCl}_{3}\right) \delta 3.66(\mathrm{~s}, 3 \mathrm{H}), 3.65(\mathrm{~s}, 3 \mathrm{H}), 3.60(\mathrm{~s}, 3 \mathrm{H}), 2.84-2.76(\mathrm{~m}, 1 \mathrm{H}), 2.51(\mathrm{dd}, J=14.2,8.2 \mathrm{~Hz}$, $1 \mathrm{H}), 2.34$ (t, $J=8.0 \mathrm{~Hz}, 1 \mathrm{H}), 2.30(\mathrm{t}, J=8.0 \mathrm{~Hz}, 1 \mathrm{H}), 2.27-2.24(\mathrm{~m}, 1 \mathrm{H}), 2.20$ (t, $J=10.3 \mathrm{~Hz}$, $1 \mathrm{H}), 1.97(\mathrm{dd}, J=14.2,5.3 \mathrm{~Hz}, 1 \mathrm{H}), 1.96-1.90(\mathrm{~m}, 1 \mathrm{H}), 1.69-1.58(\mathrm{~m}, 4 \mathrm{H}), 1.51-1.46(\mathrm{~m}, 1 \mathrm{H})$, $1.15(\mathrm{dt}, J=13.3,6.6 \mathrm{~Hz}, 1 \mathrm{H}) ;{ }^{13} \mathrm{C}$ NMR $\left(75 \mathrm{MHz}, \mathrm{CDCl}_{3 .}\right) \delta 175.7,172.51,172.50,62.7,59.8$, 56.7, 54.9, 52.73, 52.65, 51.7, 51.6, 48.4, 38.8, 36.3, 36.1, 30.0, 29.9, 26.0; LRMS m/z 339 $\left(\mathrm{M}^{+}+1\right)$; HRMS $\mathrm{m} / \mathrm{z}$ calcd for $\mathrm{C}_{19} \mathrm{H}_{27} \mathrm{O}_{6}\left(\mathrm{M}^{+}+1\right) 339.1808$, found 339.1790.

\section{Acknowledgements}

This work was partly supported by a Grant-in-Aid for Encouragement of Young Scientists, JSPS Postdoctoral Fellowship (for S.M.) and a Grant-in-Aid for Scientific Research on Priority Areas (A) "Exploration of Multi Element Cyclic Molecules" from the Ministry of Education, Culture, Sports, Science and Technology, Japan.

\section{References and Notes}

1. (a) Giese, B. Radical in Organic Synthesis: Formation of Carbon-Carbon Bonds, Pergamon, Oxford, 1986. (b) Curran, D. P. In Comprehensive Organic Synthesis, by Trost, B. M.; Fleming, I. ; Semmelhack, M. F. Ed.; Pergamon: Oxford, 1991; Vol. 4, p 715.

2. (a) Jasperse, C. P.; Curran, D. P.; Fevig, T. L. Chem. Rev. 1991, 91, 1237. (b) Malacria, M. Chem. Rev. 1996, 96, 289. (c) Bowman, W. R.; Bridge, C. F.; Brookes, P. J. Chem. Soc., Perkin Trans. 1 2000, 1. (d) Takasu, K.; Kuroyanagi, J.; Ihara, M. Org. Lett. 2000, 2, 3579. (e) Kelly, D. R.; Picton, M. R. J. Chem. Soc., Perkin Trans. 1 2000, 1571. (f) Takasu, K.; Ohsato, H.; Kuroyanagi, J.; Ihara, M. J. Org. Chem. 2002, 67, 6001.

3. (a) Beckwith, A. L. J. Tetrahedron 1981, 37, 3073. (b) Beckwith, A. L. J.; Schiesser, C. H. Tetrahedron 1985, 41, 3925.

4. (a) Stork, G.; Mook, Jr., R. J. Am. Chem. Soc. 1983, 105, 3720. (b) Curran, D. P.; Rakiewicz, D. M. J. Am. Chem. Soc. 1985, 107, 1448. (c) Takahashi, T.; Tomida, S.; Sakamoto, Y.; Yamada, H. J. Org. Chem. 1997, 62, 1912. (d) Katsumata, A.; Takasu, K.; Ihara, M. Heterocycles 1999, 51, 733.

5. (a) Dombroski, M. A.; Kates, S. A.; Snider, B. B. J. Am. Chem. Soc. 1990, 112, 2759. (b) Zoretic, P. A.; Weng, X.; Casper, M. L.; Davis, D. G. Tetrahedron Lett. 1991, 32, 4819. (c) Batsanov, A.; Chen, L.; Gill, G. B.; Pattenden, G. J. Chem. Soc., Perkin Trans. 1 1996, 45.

6. Beckwith, A. L. J.; O'Shea, D. M. Tetrahedron Lett. 1986, 27, 4525. 
7. Stork, G.; Mook, R., Jr. Tetrahedron Lett. 1986, 27, 4529.

8. A part of this work was published as preliminary communication: (a) Takasu, K.; Kuroyanagi, J.; Katsumata, A.; Ihara, M. Tetrahedron Lett. 1999, 40, 6277. (b) Takasu, K.; Maiti, S.; Katsumata, A.; Ihara, M. Tetrahedron Lett. 2001, 42, 2157.

9. Marshall, J. A.; Shearer, B. G.; Crooks, S. L. J. Org. Chem. 1987, 52, 1236.

10. Stork, G.; Zhao, K. Tetrahedron Lett. 1989, 30, 2173.

11. Toyota, M.; Yokota, M.; Ihara, M. Tetrahedron Lett. 1999, 40, 1551.

12. Baldwin, J. E. J. Chem. Soc., Chem. Comm. 1976, 734.

13. (a) Giese, B.; Kretzschmar, G. Chem. Ber. 1983, 116, 3267. (b) Ihara, M.; Katsumata, A.; Setsu, F.; Tokunaga, Y.; Fukumoto, K. J. Org. Chem. 1996, 61, 677.

14. Dess, D. B.; Martin, J. C. J. Am. Chem. Soc. 1991, 113, 7277.

15. Ozaki, S.; Matsushita, H.; Ohmori, H. J. Chem. Soc., Chem. Commun. 1992, 1120.

16. Diastereomeric mixtures of $\mathbf{1 8}$ were converted into the corresponding ketones by the hydroboration-oxidation, followed by $\mathrm{CrO}_{3}$-oxidation. The formation of phenanthrene framework was assigned on the basis of $1710 \mathrm{~cm}^{-1}$ absorption $(\mathrm{C}=\mathrm{O})$ in IR spectrum (neat).

17. Previously, Curran depicted the radical reaction of analogous 1-iodo-1,5,10-triene. However, the reaction was unsatisfactory resulted in the production of tricyclo[6.3.0.0 $\left.0^{2,6}\right]$ undecane as an inseparable mixture of four diastereomers and another isomers. Curran, D. P.; Sun, S. Aust. J. Chem. 1995, 48, 261.

18. The reaction of tertiary alkyl radicals with intramolecular di- and tri-substituted olefin usually predominates 6-endo-trig cyclization over 5-exo-trig one. See ref. $3 \mathrm{a}$.

19. In the second cyclization of 27 , the rate of 5-exo-trig cyclization might be $\sim 100$ times faster than 3-exo-trig cyclization, which can lead to homoallyl-homoallyl radical rearrangement. For a review of kinetics of radical cyclizations, see: Griller, D.; Ingold, K. U. Acc. Chem. Res. 1980, 13, 317. 